\title{
Trauma Symptoms, Perceived Social Support, Emotional Competence and Self-Esteem as Predictors of Nursing School Teachers' Behavior Styles in Social Conflicts
}

\author{
Nataša Vlah, Sanja Tatalović Vorkapić \\ Faculty of Teacher Education, University of Rijeka, Croatia
}

\begin{abstract}
The aims of the study were to analyse the relationship between three styles used in social conflicts (cooperation, avoiding/adapting and winning) and some personality traits shared by future nursery school teachers, and to explore the possibility of predicting styles used in social conflicts on the basis of these traits. One hundred and seven students of Early and Preschool Education in Rijeka ( $M=23$ years, $98 \%$ female students) completed a questionnaire that integrated the Scale of Attitudes Towards Behavioural Styles in Social Conflicts (Vlah, 2013), Trauma Symptoms Checklist (Šimić, Sesar, \& Barišić, 2012), Social Support Appraisals Scale (Kurtović, 2013), Emotional Skills and Competence Questionnaire (Takšić, 2002), and Rosenberg Self-Esteem Scale (1979). Descriptive, correlation and regression analyses were used to analyse the data. All three styles used in social conflicts were correlated to other research variables. Older students and those more competent in perceiving and understanding emotions and those with higher self-esteem with regard to oneself are significantly more oriented towards the cooperation style. The avoiding/adapting style can be predicted on the basis of students' somatic symptoms, while trauma symptoms present in students predict the winning style.
\end{abstract}

Keywords: avoiding, cooperation, self-assessment, students, winning

\section{Introduction}

Are particular knowledge and skills the only things that make a good nursery school teacher or are some other specific personal characteristics belonging to socalled implicit pedagogy also needed? It is well-known that the faculties of teacher education in the Republic of Croatia educate and train the students of early and preschool education for their professional role as nursery school teachers. However,

Nataša Vlah, Faculty of Teacher Education, University of Rijeka, Sveučilišna avenija 6, 51000, Rijeka, Croatia. E-mail: natasa.vlah@uniri.hr

This work has been fully supported by/supported in part by the University of Rijeka under the project number 13.10.2.2.03. 
we do not know whether study programmes provide conditions not only for the professional development of future nursery school teachers but also for their personal growth. In order to ensure quality work with children of early and preschool age, it is extremely important - along with specialist knowledge and skills that adequately prepare nursery school teachers for quality and competent work with preschool children - to also focus on other characteristics shared by nursery school teachers that are prominent in implicit cognition (Jančec, Tatalović Vorkapić, \& Lepičnik Vodopivec, 2015; Tatalović Vorkapić, 2015). One of important nursery school teachers' characteristics contributing to a child's healthy socio-emotional development is also the skill to manage social conflicts. According to a number of authors, nursery school teachers with knowledge, skills and positive attitudes towards constructive behaviour in social conflict resolution know how and are able to create an environment, as well as plan and realize programmes, in which children develop their own social competencies (Allen, 2009; Betz, 1994; Dusi, Steinbach, \& Messetti, 2012; Gross, 2013; Jenkins, Ritblatt, \& McDonald, 2008; Keles \& Alisinanoglu, 2012). Taking into consideration the scarcity of research into competencies of nursery school teachers relating to personality and the contribution of personality traits to attitudes towards behaviour in conflicts, the authors of this paper found it interesting to analyse these very concepts in the students of early and preschool education at one Croatian faculty of teacher education, in order to give suggestions for improving the programme of study and the study environment.

Social conflict is a communication process in interpersonal relationships in which parties to a conflict "primarily perceive the incompatibility of aims, understanding, assessments, desires, interests, values and attitudes, and express their emotions, behaviour, tendencies and states in an entirely unique way" (Vlah, 2013, p. 22). The outcome of this process and, consequently, the quality of interpersonal relationships depend on constructive behaviour before, after and during the conflict itself. Although there are several classifications of behavioural styles ${ }^{1}$ used in social conflicts, this paper is based on a classification into three styles, cooperation, avoiding/adapting and winning, which served as the criterion variables in this study. Research on students and teachers in Croatia has shown that they mainly have positive attitudes towards the cooperation style, that avoiding/adapting is partly accepted or rejected, and that winning is generally rejected (Vlah, Jančec, \& Ćepić, 2015; Vlah \& Pinoza-Kukurin, 2012). Regarding the benefit to interpersonal relationships (Vlah, 2013; Weeks, 2000; Kilman \& Thomas, 1975; as quoted in Wilmot \& Hocker, 1998), of the three styles mentioned, cooperation is considered to be the only completely constructive behavioural style used in conflicts. Avoiding/adapting and winning are non-constructive behavioural styles in conflict resolution, with winning being especially dangerous and destructive because it

\footnotetext{
${ }^{1}$ Behavioural styles are determined biosocially by the evolution of the human species, and are learned at the individual level in primary and secondary socialization groups.
} 
borders on violent behaviour. Both non-constructive styles have been linked with traumatic experiences during growing-up.

Trauma symptoms are caused by traumatic events that mostly exist outside the limits of the usual human experience. These are distinctly subjectively unpleasant situations of threatened safety and/or situations that result in the feeling of being overwhelmed and lonely, even if physical symptoms are not present (Arambašić, 1996; Robinson, Smith, \& Segal, 2015). With regard to behavioural styles used in social conflicts, Reichert, Segal, and Flannery-Schroeder (2015) note that young persons with traumatic experiences tend to exhibit disruptive, avoidance and adaptive behaviour. Šimić, Sesar, and Barišić (2012) established four groups of trauma symptoms in students, which can result from one or more types of abuse: anxiety and depression, trauma symptoms, somatic symptoms, and sexual problems and difficulties. Young persons with a childhood traumatic experience can exhibit a series of trauma symptoms, including sexual problems and difficulties (Gamache, Ryzin, \& Dishion 2016). Anxiety is a subjective anticipation of a threat and is connected to biological and psychosocial factors (Merkaš, 2004); depression is a mental state of low spirits, dejection, sadness, melancholy, despondency, gloominess, dullness and apathy (Merkaš, 2004). Somatic symptoms generally are physical discomforts without a clear physiological aetiology, which can be related to any part of the body, such as headaches, limb pain, and difficulties and aches in certain parts of the cardiovascular and digestive systems. When a teacher is reminded of a previous traumatic experience, this can lead to difficulties in coping with problems and have a serious impact on his/her ability to adapt (Howell et al., 2015). Research has linked avoidance behaviour to posttraumatic symptoms (Shenk, Putam, \& Noll, 2012), and avoidance behaviour and difficulties in coping with problems have been observed in sexually traumatised women (Shin et al., 2015). Many studies point to a predictive contribution of traumatic experiences to violent types of behaviour (Ardino, 2011; Foy, Furrow, \& McManus, 2011; Hamner, 2008; Weeks \& Widom, 1998).

Social support is a communicative means achieved through interaction with other people (Karačić, 2012), and, in this sense, refers to activities that are, on behalf of a person, performed by other, significant, people (e.g. family members, relatives, friends, co-workers, neighbours). Since behavioural styles used in social conflicts are learned a in social environment and are directly linked to the social support, it is important to analyse social support as a variable in relation to behavioural styles used in social conflicts. The individual perception of received support is more important than support available and received in reality (Kregar, 2004) and it is for this reason that research into social support has mainly been focused on respondents' perception. Social support can be perceived from a variety of sources. Regarding the social networks from which social support can be perceived, there is perceived support from family, from friends and peers, and from co-workers or superiors at work; and persons with more friends, acquaintances etc. are those with more access to 
instrumental and emotional support (Cohen \& Wills, 1985; Kurtović, 2013; Vaux et al., 1986). In comparison to students who do not receive social support, the academic achievements of students who do receive social support from friends and family members improve, as do their problem-solving skills; their self-esteem is higher and they feel more valued (Kahriman \& Yesilcicek, 2007; as quoted in Özbey, 2012). There is also an important effect of social support on reducing anxiety and depression and improving the quality of life (Abbey, Abramis, \& Caplan, 1985). According to Hung (2012), seeking social support is considered the most important strategy nursery school teachers use in problem-solving. A positive correlation has been found between a higher level of perceived social support and greater job and life satisfaction (Fiala \& Sindik, 2013; Hrupački \& Sindik, 2013). Students report the highest level of support from family members and the lowest from teachers (Kurtović, 2013). Dyadic relationships play an important role in the experience of social support and relationships in which conflict is not satisfactorily resolved or relationships characterised by poor adjustment may have negative consequences for the experience of social support (Pretorius, 1997).

One of the fundamental components of constructive behaviour used in social conflict resolution is emotional competence; it is, therefore, sound to expect a significant correlation between this variable and styles used in social conflicts. Emotional competence is a prerequisite for that kind of ability to acquire emotional maturity that will ensure effective and realistic assessment as well as timely and adequate reaction in socially demanding situations (Arnold, 2008; Reić Ercegovac, Koludrović, \& Jukić 2009). Chabot (2009, p. 87) points out the importance of emotional competence in a teacher, which then he/she encourages in his/her students: "the real learning process takes place when we feel rather than when we understand". Takšić (2002) defines emotional competence as a construct within which emotional intelligence is defined as a personality trait. Developing his instrument for measuring emotional intelligence based on the Mayer-Salovey model (1995), Takšić (2002) pointed out that emotional competence consists of three competencies: perceiving and understanding emotions; expressing and labelling emotions; and regulating and managing emotions. Higher levels of emotional intelligence positively correlate with cooperation as a conflict resolution style and negatively with accommodating conflict resolution style (Morrison, 2008). The predictive contribution of higher levels of emotional competence to non-violent behaviour has been found in university students (Adesina, 2012), and Rangan and Chandrika (2003) found emotional intelligence to be an important element in predicting successful conflict resolution in the workplace.

Self-esteem is the evaluative aspect of self-concept. It is reasonable to suppose that self-concept has an important role in interpreting opinion, emotions and behaviour (Bezinović, 1988). Therefore, it is also necessary to analyse self-esteem in studies of important characteristics shared by nursery school teachers. Of the existing great number or theoretical models, we started from Rosenberg's self-concept model 
(1979). This theoretical model echoes the foundations of James (1890; as quoted in Lacković-Grgin, 1994) and Cooley (1902; as quoted in Lacković-Grgin, 1994), which postulate that a person possesses a general feeling of his/her own value, which goes beyond the self-evaluation in individual, narrow and specific, areas of life. This starting point implies that a person has a certain global self-esteem, i.e. what he/she thinks about himself/herself as a personality. Self-esteem is a component consisting of individual aspects of self-concept and is superordinate to its other categories. Here it is important to point out that the same model differentiates between inner selfesteem, which is founded and acquired on the basis of one's own experiences of the self, and outer self-esteem, based on the appraisals of significant others. Higher selfesteem in nursery school teachers is positively correlated with the awareness of constructive behavioural modes in conflict-handling (Hay, Byrne, \& Butler, 2000; Rodríguez-Ruiz, Rodrigo, \& Martínez-González, 2015), whereas lower self-esteem is correlated with the approval of aggression in conflict resolution (Diaz-Aguado \& Martinez, 2015).

Why are these characteristics important for future nursery school teachers, who will work with children of early and preschool age? We are of the opinion that, in addition to specific knowledge in general areas ${ }^{2}$, these characteristics are extremely important for quality work with children of early and preschool age because in their everyday work, nursery school teachers communicate with children, present them with models of behaviour and steer activities by providing different kinds of social corroboration. The abilities of nursery school teachers as mediators in conflict resolution among children are significantly correlated with their self-assessment abilities (Lieberman, Foux-Levy, \& Segal, 2005). Our academic interest is precisely in those characteristics of nursery school teachers that can be expected to directly contribute to constructive behaviour with children.

The main aim of this study was (I) to analyse the relationships among styles used in social conflicts, trauma symptoms, social support, emotional competence and self-esteem in future nursery school teachers, and, with special interest, (II) to explore the possibility of predicting styles used in social conflicts based on these variables. The first research problem was to establish the descriptive parameters of all these variables. The second research problem was to establish the relationship among the focal variables in the study, as well as their relationship with students' age. The third research problem would answer the question in connection with the possibility of predicting social conflict resolution styles preferred by future nursery school teachers on the basis of trauma symptoms, social support, emotional competence and selfesteem. Since the sample consisted of students with a certain study specialisation, higher values were expected on all measured variables except trauma symptoms. Furthermore, significant negative correlation was expected between the constructive style in social conflict resolution and trauma symptoms, while significant positive

2 Such as developmental psychology, sociology, family and preschool pedagogy, kinesiology, educational rehabilitation, as well as the didactic areas of music and art. 
correlation was expected between these conflict resolution styles and high social support, high emotional competence and high self-esteem. In connection to this, the low level of trauma symptoms, the high level of social support, the high level of emotional competence and high self-esteem were expected to be significant predictors of the constructive style used in social conflict resolution. In order to achieve the objectives, a cross-sectional correlational study was carried out.

\section{Method}

\section{Participants}

Participants in the study were 107 students of the first $(N=24 ; 22.4 \%)$, second $(N=27 ; 25.2 \%)$ and third $(N=24 ; 22.4 \%)$ year of the full-time Early and Preschool Education Undergraduate Study and the first year $(N=32 ; 29.9 \%)$ of the Early and Preschool Education Graduate Study at the Faculty of Teacher Education in Rijeka. Of the total number, 105 (98.1\%) were women (male students were not separated from the total sample, since the results were not different). The average age was 23 years, ranging from 18 to 45 .

\section{Instruments}

Behavioural styles used in social conflicts were measured using the Scale of Attitudes towards Behavioural Styles of Adolescents in Social Conflicts (Vlah, 2013), which consists of a total of 22 items, grouped into three subscales: the cooperation style $(N=7 ; \alpha=.81 ; \mathrm{K}-\mathrm{Sz}=.19, p=.00$; "Recognizing the opinions of the other party to a conflict is beneficial to everyone"), the avoiding/adapting style ( $N=8 ; \alpha=.80$; K$\mathrm{Sz}=.13, p=.00$; "It is best to avoid uncomfortable conversations and situations"), and the winning style $(N=7 ; \alpha=.80 ; \mathrm{K}-\mathrm{Sz}=.20, p=.00$; "Trying to become and remain a winner is important"). Respondents marked their level of agreement or disagreement with each statement on a four-point Likert scale (from 0, "I do not agree at all", to 3, "I completely agree").

The Trauma Symptoms Checklist - 40 (Briere \& Runtz, 1989; as quoted in Šimić et al., 2012), translated and validated on a sample of students, was used to measure the self-assessment of trauma symptoms. Originally, it consists of a total of 40 items grouped into four subscales, whose factor structure was confirmed in this study with some item reduction: the anxiety and depression dimension $(N=7 ; \alpha=.83 ; \mathrm{K}-\mathrm{Sz}=.12$, $p=.00$; "Feeling isolated from others"), the somatic symptoms dimension $(N=5$; $\alpha=.65 ; \mathrm{K}-\mathrm{Sz}=.16, p=.00$; "Headaches"), the sexual problems and difficulties dimension ( $N=2 ; \alpha=.68 ; \mathrm{K}-\mathrm{Sz}=.47, p=.00$; "Bad thoughts or feelings during sex"), and the trauma symptoms dimension $(N=5 ; \alpha=.70 ; \mathrm{K}-\mathrm{Sz}=.32, p=.00$; "Desire to physically hurt yourself"). Only items with high discriminative coefficients 
(according to criteria higher than .04) were kept and the represented the original dimensions. The respondents rated the frequency of experiencing each of the items during the past two months on a four-point Likert scale (from 0, "Never" to 3, "Very often").

Perceived social support was measured using the adapted Social Support Appraisals Scale (SS-A Scale; Vaux et al., 1986; as quoted in Kurtović, 2013). Kurtović (2013) adapted the scale on a sample of students by altering the contents of the original dimension of social support at work into a dimension of social support from university teachers. The questionnaire originally consists of a total of 24 items grouped into three subscales, whose factor structure was confirmed with some item reduction: perceived social support within family $(N=7 ; \alpha=.92 ; \mathrm{K}-\mathrm{Sz}=.29, p=.00$; "My family respects me"), perceived social support from friends $(N=7 ; \alpha=.94 ; \mathrm{K}$ $\mathrm{Sz}=.12, p=.00$; "My friends respect me") and perceived social support from university teachers $(N=6 ; \alpha=.84 ; \mathrm{K}-\mathrm{Sz}=.11, p=.00$; "I feel accepted by my university teachers"). Same as previously, only items with high discriminative coefficients (according to criteria higher than .40) were kept and the represented the original dimensions. Respondents chose answers on a five-point Likert scale (from 1, "Does not apply to me at all" to 5, "Completely applies to me").

The Emotional Skills and Competence Questionnaire (ESCQ-15; Takšić, 2002) was employed to ascertain students' self-assessment of emotional competence. It originally consists of 15 items, grouped into three subscales, whose factor structure was confirmed with one item excluded: the dimension of the ability to perceive and understand emotions $(N=5 ; \alpha=.77 ; \mathrm{K}-\mathrm{Sz}=.13, p=.00$; "I am able to tell the difference between my friend being sad and being disappointed"), the dimension of the ability to express and label emotions $(N=4 ; \alpha=.85 ; \mathrm{K}-\mathrm{Sz}=.10, p=.02$; "I am able to express my emotions well", and the dimension of the ability to manage emotions $(N=5$; $\alpha=.58 ; \mathrm{K}-\mathrm{Sz}=.12, p=.02$; "I am able to maintain a good mood even if something bad happens"). Students expressed their opinions about themselves on each statement by circling a number on a five-point Likert scale (from 1, "Not at all" to 5, "Yes, completely").

In order to measure self-esteem, the Rosenberg Self-Esteem Scale (Rosenberg, 1979) was used. The questionnaire originally consists of a total of 10 items and is known as a single-factor structure; however, a two-factor structure was established in our study, distinguishing two dimensions that were reflected in the following two subscales: inner self-esteem $(N=5 ; \alpha=.78 ; \mathrm{K}-\mathrm{Sz}=.93, p=.02$; "I certainly feel useless at times") and outer self-esteem $(N=4 ; \alpha=.80 ; \mathrm{K}-\mathrm{Sz}=.17, p=.00$; "I feel that I am a person of worth, at least on an equal plane with others"). Respondents assessed the items on a five-point Likert scale (from 0, "Not at all" to 4, "Completely") with regard to the degree in which the statement was true for them. 


\section{Procedure}

The data were collected in class time in the academic year 2014/2015. Four female students participated in the project and administered the questionnaire during class, as part of their final papers. The completion of the questionnaire was anonymous and voluntary, and took 15-20 minutes.

\section{Results}

The hypotheses were tested using descriptive statistics, Spearman's correlation - due to the significant deviation from normal distribution found in the results of the focal variables - and hierarchical regression analyses, with all predictor variables being examined in the first model of analysis, and age being considered in the second model of analysis.

The results will be presented with regard to the two aims and three research problems.

\section{Descriptive and Correlation Indicators of Conflict Resolution Styles, Trauma Symptoms, Social Support, Emotional Competence and Self-Esteem Obtained on a Student Sample}

In connection to the first and second research problems, descriptive and correlation analyses were conducted, the results of which are shown in Table 1 . The analysis of average values relating to the three different behavioural styles used in conflicts revealed that students scored highest on cooperation. A significantly lower mean value was found in their scores on the avoiding/adapting style, and they scored lowest on the winning style: they mostly did not agree with the statements relating to these two styles. Further, regarding the trauma symptoms scale, the highest mean was found on the somatic symptoms and the experience of anxiety and depression subscales - the students experienced them sometimes. On the other hand, very low average values were established on sexual problems and difficulties and trauma symptoms subscales, which they almost never experienced. According to the results on the social support scale, the students had very high average scores on the support they received from family members, and considered it almost complete. They mainly agreed with the statements regarding social support from their friends, while they were mostly undecided with regard to the support received from teachers. Regarding emotional competence, the students showed the highest level of competence in perceiving and understanding emotions, followed by expressing and labelling emotions, which, according to their assessment, usually occurs, and, finally, in regulating and managing emotions, which sometimes occurs. Assessing their selfesteem as rather high, they scored, on average, a higher level of outer self-esteem, and a lower level of inner self-esteem. 


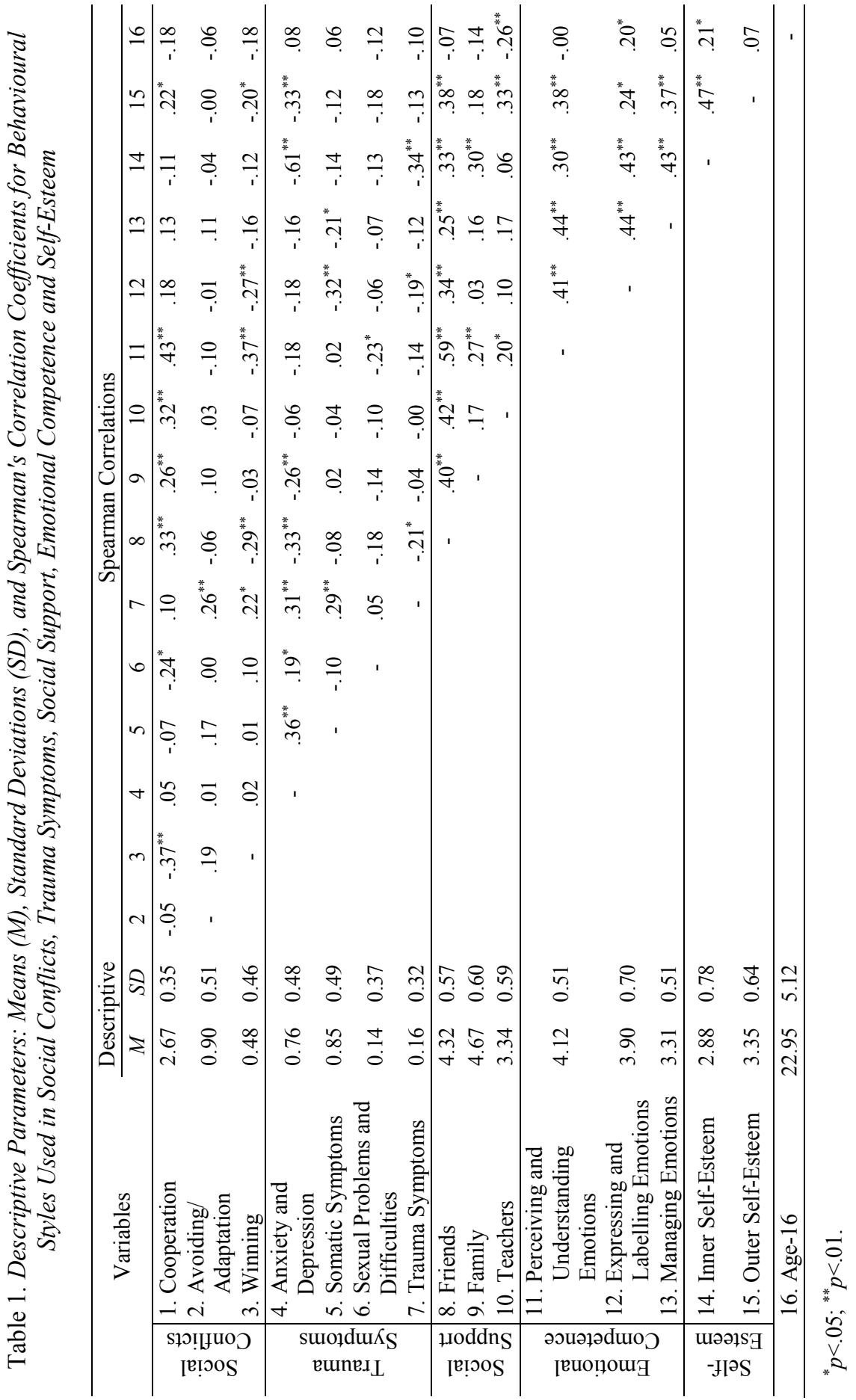


The analysis of the established correlation matrix, also shown in Table 1, indicated that students' conflict resolution styles were significantly correlated with their assessments on individual subscales. Thus, the intercorrelation of the styles themselves revealed the expected direction and level of correlations, with the negative correlation between cooperation and winning being the only significant one. The relationships among the four subscales of trauma symptoms, the highest and most consistent significant positive correlation were found for the anxiety and depression subscale. The results on this subscale were significantly positively correlated with all other subscales of trauma symptoms. The intercorrelation between different types of social support showed significant positive correlations between social support from friends with the other two, while no correlation was found between support received from family members and that from teachers. The intercorrelations that were established among the examined domains within students' emotional competence revealed significant positive correlations between all three domains. Regarding the variable of age, inner self-esteem was found to be significantly higher in older students, while support from teachers was significantly lower.

\section{Results of the Hierarchical Regression Analyses for the Three Criteria: The Cooperation Style, the Avoiding Style and the Winning Style}

The third research problem attempted to solve the issue relating to the possibility of predicting social conflict resolution styles used by future nursery school teachers on the basis of trauma symptoms, social support, emotional competence and selfesteem. The results of the hierarchical regression analysis are displayed in Table 2. The analysis revealed that perceiving and understanding emotions (within emotional competence), inner self-esteem and students' age were significant predictors of the cooperation style. Older students, students with a higher level of competence in expressing and understanding emotions, and those with higher inner self-esteem are likely to be significantly more oriented towards using the cooperation style in social conflicts resolution.

In addition, the results showed that the use of the avoiding/adapting style may most efficiently be predicted on the basis of a positive significant predictor - the presence of somatic symptoms in students. On the other hand, a higher level of trauma symptoms present in students best predicted the use of the winning style. 


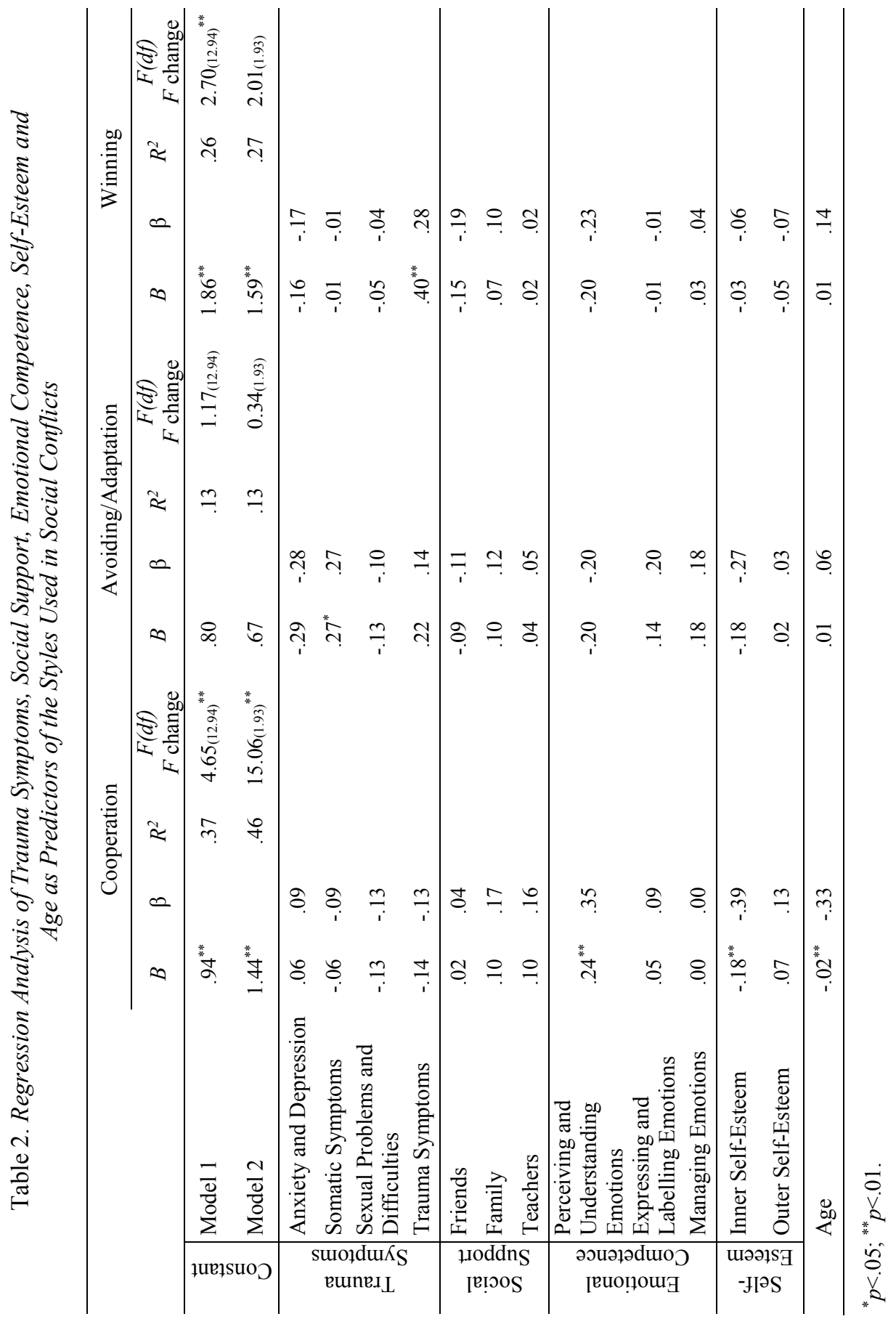




\section{Discussion}

The initial hypotheses were mainly confirmed. The scope of predicting behavioural styles, which is the most interesting part of this paper, is somewhat narrower than was assumed. In non-constructive conflict resolution styles, it is reduced to trauma symptoms, and in the constructive behavioural style used in conflict resolution, it is reduced to emotional competence, older age and inner selfesteem.

The descriptive parameters of focal variables relating to future nursery school teachers mostly confirm previous findings of research done on students and teachers (Kurtović, 2013; Šimić et al., 2012; Takšić, 2002; Vlah \& Pinoza-Kukurin, 2012; Vlah et al., 2015). A higher value found on the cooperation style, perceived social support from family and friends, the basic levels of emotional competence and outer self-esteem, and lower values found on trauma symptoms empirically contribute to the characteristics of a professional profile that is expected in future teachers working with children of early and preschool age (Jančec et al., 2015; Tatalović Vorkapić, 2015). It is desirable and appropriate to employ persons in this profession who have the described personality and behavioural profile, persons who are willing to have a dialogue, to understand and acknowledge the needs, aims and desires of the other party in a conflict, and to search for alternative solutions. Positive correlations between cooperation style and all types of social support, perceiving and understanding emotions and high self-esteem confirms the findings of previous research on the rules of constructive behavioural styles used in conflict in general (Diaz-Aguado \& Martinez, 2015; Hay, 2000; Lieberman et al., 2005; RodríguezRuiz et al., 2015; Weeks, 2000; Wilmot \& Hocker, 1998). However, with regard to predicting the use of the cooperation style, it is obvious that cooperation as a style used in social conflicts will significantly more often be found in future nursery school teachers who better perceive and understand emotions - as in Morrison, (2008), Adesina, (2012), and Rangan and Chandrika (2003) - as well as in those who are older (which may be related to life experience) and those who have higher inner selfesteem with regard to oneself (i.e. the inner self, or the identity based on what I think of myself, which may be considered the basis of self-esteem).

Our students have very good experiences in receiving social support from their family members, as their first significant adults, which is followed by support from friends; this, in the profession of educating children, forms the basis for one's giving support to others. Furthermore, such teachers are the ones needed in nursery schools because they have greater job satisfaction and better relationships with their coworkers (Fiala \& Sindik, 2013; Hrupački \& Sindik, 2013). A high level of perceived social support is correlated with lower levels of anxiety and depression, higher emotional competence and self-esteem, which supports previous findings (Abby et al., 1985; Özbey, 2012), and suggests the need for creating a particular academic environment within a study course, oriented towards desired outcomes. Furthermore, 
it is good that students' self-assessment of the ability to perceive, understand, express and label emotions is high, because these characteristics are important for their role as models to children who are in the process of emotional development. No less is the role of these characteristics when, in their work, nursery school teachers find themselves in different demanding socio-emotional situations in group work, where they have to make efficient and realistic assessments, and react and respond appropriately (Arnold, 2008; Reić Ercegovac et al., 2009).

Students also showed high self-esteem, especially when assessing it in comparison between themselves and others, which points to their positioning in the social context and the importance they attach to what they think others think of them. The Rosenberg scale revealed two dimensions and students' self-esteem was found to be somewhat lower when assessing themselves in relation to their own expectations of themselves. This type of self-esteem is present in older students - not a small number of whom already work in the profession - who have probably developed specific inner self-appraisal both in their personal life and work experience. It is interesting to note that this type of self-esteem is positively correlated with social support from family and friends, while higher outer self-esteem correlates with social support from teachers. Does it mean that students' self-concept based on the verbal and non-verbal feedback received from teachers is different from the one based on the feedback received from family members and friends, and that teachers' opinions are for them the criterion of outer evaluation? If the answer is yes, then support from teachers - although its score is, as in Kurtović (2013), the lowest of the three - is extremely important for their professional development in the terms of implicit pedagogy, i.e. pedagogy that is transmitted via non-formal channels. An answer to this and similar questions may be sought in future research.

Students sometimes exhibit symptoms of depression and anxiety, as well as somatic symptoms, while they almost never have sexual difficulties and trauma symptoms. From the viewpoint of their profession, lower values would be even more desirable in future nursery school teachers. Students scored a lower, but still visible, level of somatization, anxiety and depression, pointing to some traumatic, subjectively unpleasant, experiences they have had in their life so far or are still having, which have not been successfully resolved, and which, probably to a greater or lesser extent, interfere with their everyday personal and social functioning (Robinson et al., 2015). This is an indication on which a formal or non-formal university curriculum may have an intervening influence. Somatization, although the reliability of the subscale is low and the result should be viewed with certain reservations, proved to be a significant predictor of the avoiding/adapting style used in social conflict resolution, confirming the theory of the avoidance phenomenon in conflict-handling (Reichert et al., 2015; Shenk et al., 2012; Weeks, 2000; Wilmot \& Hocker, 1998). This implies that nursery school teachers who repress unresolved traumatic experiences, manifested as somatization, will probably, in a situation when they should stand up for themselves or the child that has been left in their care, resort 
to avoiding or retreating and adapting rather than try to solve the problem. Somatization is represented by observable manifestations such as headaches, insomnia, weight loss and so on, and if more attention were given to such students' problems during the course of study, it would probably help them, as well as the children with whom they will work one day.

The correlation between the tendency towards using the winning style in social conflicts and lower outer self-esteem, lower emotional competence in perceiving, understanding, expressing and labelling emotions, lower levels of perceived social support from friends and perceived higher levels of trauma symptoms is well-known in the theory of behavioural styles used in conflicts (Weeks, 2000; Wilmot \& Hocker, 1998), and what they amount to is a range of problems on personal and social planes leading to difficulties in socialization and social integration of a person. However, only the existence of trauma symptoms in students was revealed as a significant predictor of winning in this study - specifically, desire to physically injure oneself, unnecessary or over-frequent washing, and desire to hurt others as well, which is similar to findings obtained earlier (Ardino, 2011; Foy et al., 2011; Hamner, 2008; Weeks \& Widom, 1998). This is also a powerful indicator suggesting the need to detect students manifesting mentioned characteristics before they start working with children so that they can be provided with adequate psychological help. Regarding the question posed in the introduction, whether study programmes provide conditions for both personal and professional development of future nursery school teachers, and in connection to students from this sample, it is important to mention that there is a University Counselling Centre $^{3}$ at the University of Rijeka, offering psychological counselling to students. However, although there are indications, not one student from the sample was included in the treatment. Why is this so is a question for future research. It is important to emphasise the significant prediction power of emotional competency and self-esteem regarding the style of cooperation in conflicts. In previous research it could be noticed that self-esteem and emotional competency have strong determination effect on social skills such as cooperation. Even though, in this research it was determined that these two variables are not protective factors for non-constructive behavioural styles, as winning and avoiding. However, they have a negative correlation with winning and avoiding, what could provide the significant prediction power if the research sample was larger. Using the larger and non-random sample could be solid guidelines for future research.

With regard to the established aim of the paper, it is important to give some recommendations for improving the study programme that trains future nursery school teachers. It is necessary - either on a formal level through compulsory subjects, such as Social Skills Training and Emotional Intelligence, or through informal activities, such as diverse student projects and opportunities for improving self-esteem and training the complex abilities of emotional competence, e.g.

\footnotetext{
${ }^{3}$ http://www.ssc.uniri.hr/hr/
} 
managing emotions, or even through more efficient collaboration with the Psychological Counselling Service - to provide our students with an environment in which they can overcome trauma symptoms and learn to use, as well as practice using, constructive behaviour in social conflicts.

The results obtained in this study confirmed the findings of earlier studies. Students' somatic symptoms and experience of anxiety and depression scored highest, and the greatest social support came from family members. Students were emotionally most competent in the domain of perceiving and understanding emotions, and they achieved higher scores on outer self-esteem than they did on inner self-esteem. Correlation analyses revealed significant correlations between all three conflict resolution styles and other research variables. Regression analyses showed that older students and students who were more competent in expressing and understanding emotions with higher inner self-esteem were significantly more prone to use the cooperation style. The avoiding style can most efficiently be predicted on the basis of somatic symptoms present in students, and the winning style on the basis of a higher level of trauma symptoms. The results obtained confirm the hypotheses and imply the significance of students' personal growth and development during the course of study in the terms of strengthening their self-esteem, emotional competence and social support, and alleviating trauma symptoms, which has an indirect impact on a more frequent use of the cooperation style in social conflicts.

In considering these research findings, one should be aware of certain study limitations, such as non-random sample, small sample size and relatively low internal consistency reliable in some measure subscales. Larger and non-random sample with more reliable measuring instruments would ensure more validation and reliable research results. This is important also regarding the fact that hierarchical regression analyses were applied, even though some results were significantly different from normal distribution.

Future studies should replicate these findings with all early and preschool education students in Croatia and examine why the factor of inner self-esteem has been singled out, as well as what is its meaning in context. They should also monitor the effects of individual university subjects that have the development of social skills and personal development as their aim, as well as the effects of other types of life experience gained during the course of study. 


\section{References}

Abbey, A., Abramis, D.J., \& Caplan, R.D. (1985). Effects of different sources of social support and social conflict on emotional well-be-ing. Basic and Applied Social Psychology, 6, 111-129.

Adesina, O. (2012). Emotional intelligence, locus of control and conflict handling skills as predictors of non-violent behaviour among university students in South Western Nigeria. Ife Psychologia, 20(2), 31-38.

Allen, S.F. (2009). A study of a violence prevention program in prekindergarten classrooms. A Journal of the National Association of Social Workers, 31(3), 177-187.

Arambašić, L. (1996). Trauma. In J. Pregrad (Ed.), Stres, trauma i oporavak (pp. 70-73). Zagreb: Društvo za psihološku pomoć.

Ardino, V. (2011). Post-traumatic stress in antisocial youth: A multifaceted reality. In V. Ardino (Ed.), Post-traumatic syndromes in children and adolescents (pp. 211-229). Chichester, UK: Wiley/Blackwell Publishers.

Arnold, K. (2008). Attachment, defensiveness, and the emotional Stroop effect. Dissertation Abstracts International: Section B: The Sciences and Engineering, 68 (10-B), Retrieved from http://eds.a.ebscohost.com/eds/detail/detail?vid=7\&sid=47a912a0-c64d-4c7ebe03-546e44300e41\%40sessionmgr4005\&hid=4208\&bdata=Jmxhbmc9a HImc210ZT11ZHMtbGl2ZQ\%3d\%3d\#AN=2008-99080-219\&db=psyh

Betz, C. (1994). Beyond time-out: Tip from a teacher. Young children, 49(3), 10-14.

Bezinović, P. (1988). Percepcija osobne kompetentnosti kao dimenzija samopoimanja. (The perception of personal competence as a self-esteem dimension). (Unpublished Doctoral Dissertation). Department of Psychology, University of Zagreb, Zagreb.

Chabot, G.W. (2009). A case study of educational needs, obstacles and opportunities for girls, women and teachers in remote Pakistan, ProQuest LLC, Ed.D. (Unpublished Doctoral Dissertation). Montana State University. USA. Retrieved from http://eds.a.ebscohost. com/eds/detail/detail?vid=15\&sid=47a912a0-c64d-4c7e-be03-546e44300e41\%40 sessionmgr4005\&hid=4208\&bdata=Jmxhbmc9aHImc210ZT11ZHMtbGl2ZQ\%3d\%3d \#AN=ED528233\&db=eric

Cohen, S., \& Wills, T.A. (1985). Stress, social support, and the buffering hypothesis. Psychological Bulletin, 98(2), 310-358.

Diaz-Aguado, M., \& Martinez, R. (2015). Types of adolescent male dating violence against women, self-esteem, and justification of dominance and aggression. Journal of Interpersonal Violence, 30(15), 2636-2658.

Dusi, P., Steinbach, M., \& Messetti, G. (2012). Citizenship education in multicultural society: Teachers' practices. Elsevier, 69(2012), 1410-1419.

Fiala, B., \& Sindik, J. (2013). Čimbenici zadovoljstva životom kod odgojiteljica predškolske djece. Acta Iadertina, 9(2), 1-14. 
Foy, D.W., Furrow, J., \& McManus, S. (2011). Exposure to violence, post-traumatic symptomatology, and criminal behaviors. In V. Ardino (Ed.), Post-traumatic syndromes in children and adolescents (pp. 199-210). Chichester, UK: Wiley/Blackwell Publishers.

Gamache, M., Van Ryzin, M., \& Dishion, T. (2016). Profiles of childhood trauma: Betrayal, frequency, and psychological distress in late adolescence. Psychological Trauma: Theory, Research, Practice, and Policy, 8(2), 206-213.

Gross, C.M. (2013). Conflict resolution in preschool: What part dues teacher mediation play. Conflict Resolution and Negotiation Journal, 6(5), 35-73.

Hamner, M. (2008). Trauma and violence. Psychiatric Times, 25(13), 20.

Hay, I., Byrne, M., \& Butler, C. (2000). Evaluation of a conflict-resolution and problemsolving programme to enhance adolescents' self-concept. British Journal of Guidance \& Counselling, 28(1), 101-113.

Howell, K., Kaplow, J., Layne, C., Benson, M., Compas, B., Katalinski, R., Pasalic, H., Bosankic, N., \& Pynoos, R. (2015). Predicting adolescent posttraumatic stress in the aftermath of war: Differential effects of coping strategies across trauma reminder, loss reminder, and family conflict domains. Anxiety, Stress \& Coping, 28(1), 88-104.

Hung, C. (2012). Job stress and coping strategies among early childhood teachers in central Taiwan. Educational Research and Reviews, 7(23), 494-501.

Hrupački, P., \& Sindik, J. (2013). Zadovoljstvo životom i karakteristike posla kod odgojiteljica. Norma, 18(1), 115-127.

Jančec, L., Tatalović Vorkapić, S., \& Lepičnik Vodopivec, J. (2015). Hidden curriculum determinants in (pre)school institutions: Implicit cognition in action. In: Z. Jin (Ed.), Exploring implicit cognition: Learning, memory, and social-cognitive processes (pp. 216-242). New York: IGI-Global, USA, doi: 10.4018/978-1-4666-6599-6

Jenkins, S., Ritblatt, S., \& McDonald, J.S. (2008). Conflict resolution among early childhood educators. Conflict Resolution Quarterly, 25(4), 429-450.

Karačić, S. (2012). Socijalna podrška kod adolescenata s tjelesnim oštećenjem. JAHR European Journal of Bioethics, 3(5), 219-243.

Keles, S., \& Alisinanoglu, F. (2012). The examination of preschool teacher candidates' peer conflict resolution suggestions during picture storybook reading. Educational sciences. Retrieved from http://www.academia.edu/2329326/The_Examination_of_Preschool_ Teacher_Candidates_Peer_Conflict_Resolution_Suggestions_during_Picture_Storybo ok_Reading

Kregar, K. (2004). Socijalna podrška djece smještene u dječjim domovima i udomiteljskim obiteljima u Republici Hrvatskoj. Ljetopis socijalnog rada, 11(2), 229-248.

Kurtović, A. (2013). Odnos perfekcionizma i socijalne podrške s anksioznošću i depresivnošću kod studenata. Medica Jadertina, 43(4), 189-200.

Lacković-Grgin, K. (1994). Samopoimanje mladih. Jastrebarsko: Naklada Slap. 
Lieberman, E., Foux-Levy, Y., \& Segal, P. (2005). Beyond basic training: A model for developing mediator competence. Conflict Resolution Quarterly, 23(2), 237-257.

Mayer, J.D., \& Salovey. P. (1995). Emotional intelligence and the construction and regulation of feelings. Applied and Preventive Psychology, 4, 197-208.

Merkaš, M. (2004). Anksiozni poremećaji. In S. Nikolić, M. Marangunić, S. Boban, ... M. Franjić (Eds.), Dječja i adolescentna psihijatrija (pp. 204-205). Zagreb: Školska knjiga.

Morrison, J. (2008). The relationship between emotional intelligence competencies and preferred conflict-handling styles. Journal of Nursing Management, 16(8), 974-983.

Özbey, S. (2012). An investigation on the relationships among burnout levels of preschool teacher trainees, certain variables and social support. International Journal of Academic Research, 4(1) 154-161.

Pretorius, T.B. (1997). The quality of dyadic relationships and the experience of social support. South African Journal of Psychology, 27(3), 171-175.

Rangan, U., \& Chandhrika, V.L. (2003). Emotional intelligence: Organisational application of EQ principles. Australian Journal of Psychology, 55, 142.

Reichert, E., Segal, C., \& Flannery-Schroeder, E. (2015). Trauma, attentional biases, and revictimization among young adults. Journal of Trauma \& Dissociation, 16(2), 181196.

Reić-Ercegovac, I., Koludrović, M., \& Jukić, T. (2009). Emocionalna kompetentnost i stres u nastavničkim zanimanjima. Zbornik radova Filozofskog fakulteta u Splitu, 2-3, 85-96.

Robinson, L., Smith, M., \& Segal, J. (2015). Emotional and psychological trauma. Retrieved from http://www.helpguide.org/articles/ptsd-trauma/emotional-and-psychological-trauma. htm

Rodríguez-Ruiz, B., Rodrigo, M., \& Martínez-González, R. (2015). Cross-contextual variability in parents' and school tutors' conflict resolution styles and positive development. Journal of Educational Research, 108(6), 480-491.

Rosenberg, M. (1979). Conceiving the self. New York: Basic Books.

Shin, K., Chang, H., Cho, S., Kim, N., Kyoung A., \& Chung, Y. (2015). Avoidance symptoms and delayed verbal memory are associated with post-traumatic stress symptoms in female victims of sexual violence. Journal of Affective Disorders, 184, 145-148.

Shenk, C.E., Putnam, F., \& Noll, J.G. (2012). Experiential avoidance and the relationship between child maltreatment and PTSD symptoms: Preliminary evidence. Child Abuse \& Neglect, 36(2), 118-126.

Šimić, N., Sesar, K., \& Barišić, M. (2012). Ček lista traumatskih simptoma, In A. Proroković, V. Ćubela Adorić, Z. Penezić, \& I. Tucak-Junaković (Eds.), Zbirka psihologijskih skala i upitnika (pp. 7-13). Sveučilište u Zadru: Zadar.

Takšić, V. (2002). Upitnici emocionalne inteligencije (kompetentnosti) UEK. In K. LackovićGrgin, A. Proroković, V. Ćubela, \& Z. Penezić (Eds.), Zbirka psihologijskih skala $i$ upitnika (pp. 10-14). Sveučilište u Zadru: Zadar. 
Tatalović Vorkapić, S. (2015). How much personality is important in educational context? In M. Orel (Ed.), International conference EDUvision 2015: "Modern approaches to teaching coming generation" (pp. 75-83). EDUvision, Stanislav Jurjevčič, Ljubljana, Slovenija. Retrieved from http://eduvision.si/Content/Docs/Zbornik\%20prispevkov $\%$ 20EDUvision\%202015.pdf

Vaux, A., Phillips, J., Holly, L., Thomson, B., Williams, D., \& Stewart, D. (1986). The Social Support Appraisal (SS-A) Scale: Studies of reliability and validity. American Journal of Community Psychology, 14, 195-219.

Vlah, N. (2013). Poželjna ponašanja mladih u konfliktima. Zagreb: Biakova d.o.o.

Vlah, N., Jančec, L., \& Čepić, R. (2015). Teachers' attitudes towards behaviour patterns in social conflicts in Primorsko-goranska County in Croatia. Center for Educational Policy Studies Journal, 5(4), 125-141.

Vlah, N., \& Pinoza-Kukurin, Z. (2012). Stavovi studenata učiteljskog fakulteta u Rijeci o obrascima ponašanja u socijalnim sukobima. Napredak, 153(1) 39-52.

Weeks, D. (2000). Osam najvažnijih koraka u rješavanju sukoba, Osijek: Sunce.

Weeks, R., \& Widom, C.S. (1998). Self-reports of early childhood victimization among incarcerated adult male felons. Journal of Interpersonal Violence, 13, 346-361.

Wilmot, W.W., \& Hocker, J.L. (1998). Interpersonal conflict. USA: McGraw-Hill.

\section{Traumatski simptomi, percepcija socijalne podrške, emocionalna kompetentnost i samopoštovanje kao prediktori obrazaca ponašanja u socijalnim sukobima budućih odgajatelja}

\section{Sažetak}

Ciljevi su istraživanja bili analizirati odnos između triju obrazaca u socijalnim sukobima (suradnja, izbjegavanje/prilagodba i pobjeđivanje) i nekih karakteristika osobnosti budućih odgajatelja, te mogućnost predviđanja obrazaca u socijalnim sukobima na temelju tih karakteristika. Studenti su ranoga i predškolskoga odgoja i obrazovanja Učiteljskoga fakulteta Sveučilišta u Rijeci ( $N=107, M=23$ godine, 98\% žene) ispunjavali upitnik u kojem su integrirane: Skala stavova prema obrascima ponašanja u socijalnim sukobima (Vlah, 2013), Skala traumatskih simptoma (Šimić, Sesar i Barišić, 2012), Skala procjene socijalne podrške (Kurtović, 2013), Upitnik emocionalnih vještina i kompetentnosti (Takšić, 2002) i Rosenbergova skala samopoštovanja (1979). Podaci su obrađeni deskriptivnom, korelacijskim i regresijskim analizama. Sva su tri obrasca u socijalnim sukobima povezana s ostalim istraživačkim varijablama. Stariji studenti i oni koji su kompetentniji u uočavanju i razumijevanju emocija te oni koji imaju veće samopoštovanje značajno su više usmjereni prema korištenju obrasca suradnje. Obrazac izbjegavanja/prilagodbe može se predvidjeti na temelju prisutnih somatskih simptoma kod studenata, a obrazac pobjeđivanja prisutnim traumatskim simptomima.

Ključne riječi: izbjegavanje, pobjeđivanje, samoprocjena, studenti, suradnja 


\title{
Síntomas de trauma, apoyo social percibido, competencia emocional y autoestima como predictores del estilo de conducta en conflictos sociales de profesores en la escuela de enfermería
}

\begin{abstract}
Resumen
El objetivo de este trabajo fue analizar la relación entre tres estilos utilizados en conflictos sociales (cooperación, evitación/adaptación y triumfo) y algunos rasgos de personalidad de los futuros profesores de la escuela de enfermería, tanto como explorar la posibilidad de predecir estilos usados en conflictos sociales basándose en estos rasgos. 107 estudiantes de Educación Preescolar en Rijeka ( $\mathrm{A}=23$ años, 98\% de estudiantes femeninas) completaron el cuestionario que integraba la Escala de Actitudes hacia los Estilos de Conducta en Conflictos Sociales (Vlah, 2013), Lista de Control de Síntomas de Trauma (Šimić et al., 2012), Escala de Evaluación del Apoyo Social (Kurtović, 2013), Cuestionario de Habilidades y Competencias Emocionales (Takšić, 2002) y Escala de Autoestima de Rosenberg (1979). Se han utilizado análisis descriptivo, correlativo y regresivo para analizar los datos. Todos los tres estilos usados en los conflictos sociales se han relacionado con otras variables de la investigación. Estudiantes mayores, aquellos más competentes en percibir y entender las emociones y aquellos con autoestima más alta están mucho más orientados hacia el estilo cooperativo. El estilo de evitación/adaptación se puede predecir a base de síntomas somáticos presentes en los estudiantes, mientras que los síntomas de trauma predicen el estilo de triumfo.
\end{abstract}

Palabras claves: evitación, cooperación, autoevaluación, estudiantes, triumfo

Primljeno: 14.09.2016. 